\title{
Development of a Conceptual Framework Regarding the Factors Affecting Academics in Higher Education's Job Dissatisfaction
}

\author{
Sujit Kumar Basak \\ Department of Information Technology, Durban University of Technology, South Africa \\ Email: sujitbasakmca@gmail.com
}

\section{Doi:10.5901/mjss.2014.v5n23p104}

\begin{abstract}
This paper presents a conceptual framework regarding the factors affecting academic job dissatisfaction in higher education, derived from an in-depth survey of the related literature. The aim of this study was achieved by identifying the factors that affect university academics' job dissatisfaction. The main result of this study is the development of a framework, derived from the existing literature, of factors affecting university academics' job dissatisfaction. The findings help to articulate issues related to university academics' job dissatisfaction and in this way contribute to the development of programs designed to address the relevant issues.
\end{abstract}

Keywords: job dissatisfaction; factors; academic; higher education;

\section{Introduction}

Education is the most important aspect of a nation or any institutional organization and it plays a crucial role in terms of development of any country (Khalid et al., 2012). In any organization employees are dissatisfied when their expectations are not met and when their working environment is not conductive. Dissatisfaction of employees can lead to reduction of productivity in the workforce, a decrease in organizational commitment and devotion and even discontinuation of the job (Payne \& Morrison, 2002; Sagie, 2002; Gellatly, 2005; Redfern, 2005; Santhapparaj et al., 2005; Denizer, 2008; Adenike, 2011). Dissatisfied employees are prone to absenteeism and excessive turnover (Sekoran and Jauch, 1978; Dickter et al., 1996; Melamed et al., 1995; Lee et al., 1999; Chen et al., 2006). According to Hoogendoorn (2011), job dissatisfaction increases the chance of the sickness of employees. Brown and Mitchell (1993) state that indirect costs associated with employees' job dissatisfaction include training, recruiting, learning curve inefficiencies and reduction in the client base. Job dissatisfaction leads to poor performance of teaching staff, so there should be a conducive working environment for employees to increase their performance with effortlessness (Sudalaiyandi et al., 2011).

\section{Problem Statement}

According to Ping du et al. (2010), employees are highly dissatisfied with their salaries and a study by Wong and Heng (2009) points out that working conditions and interpersonal relationships are two major contributors to job dissatisfaction. A study conducted by Ssesanga and Garett (2005) indicated a relationship between the working environment, promotion and academics' job dissatisfaction. Job dissatisfaction for employees is when staff members perceive a lack of support at work, are not well motivated to perform their best in the classroom, and lecturers are not completely satisfied with their working environment (Smith, 2007). According to David and Wesson (2001), limited promotion opportunities are often a cause of job dissatisfaction in any government organization. According to Madison (2000), academics that are not supported by their colleagues are usually dissatisfied with their job. Lee (1988) concludes that job dissatisfaction is one of the best predictors of turnover. Zembylas (2004) states that academics leave the teaching profession because of dissatisfaction associated with a lack of commitment, lack of productivity, reduced ability to meet student needs and psychological disorders (absenteeism, study stress, and truancy) (Hargreaves, 1994; 1998; Day, 2002; Houtte, 2006; Evdokia, 2009).

A study by Olaitan (1987) in Nigeria found that academic staff members are dissatisfied with their working conditions and academic growth. Adelabu (2005) found that in Nigeria academic staff members are dissatisfied with their living and working environment because of the salary structure compared to the other professions and related issues such as low status in society, lack of promotion, lack of career advancement opportunities, and low allowances. Another 
study in Nigeria by Akpofure et al. (2006) concluded that academics are dissatisfied with their jobs because of the salary structure. In Zimbabwe, according to Zainudin et al. (2010), the majority of academics in higher education are dissatisfied because of the high and overwhelming workload, inadequate salaries and allowances, and inability to procure loans for purchase of houses and cars (Zainudin et al., 2010).

\section{Research Question}

What are the important factors that affect academics in higher education's job dissatisfaction?

\section{Aims and Objectives}

The aim of this study was to develop a conceptual framework regarding the factors affecting academics in higher education's job dissatisfaction. This aim was achieved through accomplishing the following objectives: identifying the factors influencing higher education academics job dissatisfaction; testing the relationship to each other of these factors; examining the action and strategies that universities can take in order to improve the levels of satisfaction among academics in higher education.

\section{Literature Review}

According to Herzberg (1987), 'hygiene factors' or 'dissatisfiers' related to job satisfaction are: salary, status, security, company policy and administration, working conditions, supervision, and interpersonal relationships.

The Human Science Research Council (HSRC) in South Africa (Afrol News, n. d.) conducted a survey of 21,358 educators in more than 1,714 selected schools with a 97\% participation rate. The study revealed that academics leave their organizations due to inadequate remuneration, increased workload, lack of career advancement, lack of professional recognition, work policies, and job insecurity. A study by Chimanikire et al. (2007) indicated that the majority of academic staff members were dissatisfied with their jobs due to the high volume of work, inadequate salaries, allowances, and loans to facilitate purchase of properties.

Ssesanga and Garrett (2005) conducted a study with 182 respondents from two universities in Uganda and found that academics' dissatisfaction include extrinsic factors such as remuneration, governance, research, promotion, and working environment. A survey by Alam and Farid (2011) in Rawalpindi College concluded that the majority of the academic staff were dissatisfied with regards to low salaries. Chung (1977: 23) states that the lack of market related staff salaries can cause dissatisfaction and discontent.

Hoy and Miskel (1991: 114) conducted a study and found that top achievers being promoted very quickly can result in dissatisfaction amongst loyal and intelligent employees. Arnold and Feldman (1996: 91-91) found that job dissatisfaction amongst academics included factors such as temperature, lighting, ventilation, hygiene, noise, working hours, and resources.

Pearson and Seiler (1983) found a high rate of dissatisfaction amongst participants regarding the compensationrelated elements of their jobs such as fringe benefits, pay, and performance criteria. A study conducted by Moses (1986) concluded that academic staff members are dissatisfied due to undervaluing of teaching excellence in relation to promotion decisions.

Oshagbemi (1997), in a study conducted in the United Kingdom, found that job dissatisfaction in higher education in terms of teaching related items is caused by issues such as "sharp increases in class size, badly thought out procedures for course evaluation, public stance of university which claims to value teaching and administrative activity, little recognition of teaching skills, demands of individual students, student expansion without commensurate increases in resources, marking answer scripts, amount of marking, falling quality of intake, increasing staff/students ratios, government interference with teaching, too many students, student attitude to learning, emphasis on research at the expense of teaching and amount of mechanical teaching and marking".

Further, Oshagbemi (1997 cited in Schulze, 2006) found that job dissatisfaction in higher education in terms of research related items is caused by issues such as: "inadequate time for research, pressure to publish, erosion of time for research and personal development in specialist area, increasing difficulty with and time spent on obtaining research grants, lack of funds for research, difficulty attracting able Ph.D. students, necessity of applying for grant support, the undue importance attached to 'research', little time spent writing, research assessment exercises and lack of research facilities".

Finally, Oshagbemi (1997 cited in Schulze, 2006) found that general causes of job dissatisfaction in higher 
education includes issues such as: "poor communication with university authorities, failure to provide agreed job description, authoritarian management structure, lack of consultation and top-down communication, government policy towards universities, working hours, lack of co-ordination in management, not getting promoted unless one applies for it, lack of proper departmental strategy on teaching and research, poor retirement benefits, excessive bureaucracy, lack of leadership from the centre of the university, inconsistency in planning, location of university, changes in university funding mechanisms, not being able to retire with full benefits at 60 , lack of time to think, difficulty with managing the separate responsibilities of administration, teaching and research, and indifferent and inefficient management".

Lee (1972), Perie and Baker (1997), and Tye and O'Brien (2002) conclude from their studies that extrinsic factors such as inadequate compensation, increased paperwork, shifts in student characteristics, and negative perception of teacher, and problematic relationships with student parents/guardians contribute to academics' job dissatisfaction. Spears et al. (2000) found that job dissatisfaction is the primary reason for academics leaving their jobs.

\section{Methodology}

The strategy for identifying the main factors that affect academics' job dissatisfaction was a systematic literature review based on the following steps: formulate the review questions, define the selection criteria, and define the quality appraisal criteria (Croucher et al., 2003).

\subsection{The Review Question}

The review question provides focus and boundaries, and shapes all aspect of the review process, including: inclusion and exclusion criteria, search strategy, amount of the literature reviewed, quality appraisal, and the synthesis of evidence (Wallace et al., 2005). The review question was: what are the factors that affect academics in higher education's job dissatisfaction?

\subsection{The Search Strategy}

Google, Google Scholar and Durban University of Technology library electronic databases were searched utilising search terms such as: "factors affecting university academics' job dissatisfaction"; "job dissatisfaction academics higher education"; "factors influence university academics' job dissatisfaction".

\subsection{Application of Study Selection Criteria}

Before studies entered into systematic review, they were subjected to two filters (Wallace et al., 2005). The first filter comprised a set of inclusion and exclusion criteria so that only relevant literature able to address the review question is taken through the second filter (Wallace et al., 2005).

\subsection{Design of the Studies}

Studies included in this review are those with empirical evidence from experimental or observational research that include qualitative research. The study includes unpublished and published work (Wallace et al., 2005). In this literature review, only those articles directly associated with factors affecting university academic job dissatisfaction have been selected.

\subsection{The Quality Appraisal Criteria}

Studies included in the literature review met all five necessary elements of quality appraisal criteria as per Wallace et al. (2005) for valid and trustworthy findings. Articles selected were considerable, acceptable, reliable, and empirically valid and each study had a good research question and theory or theoretical framework.

\section{Results}

The results of this study are displayed in Figure 1. 


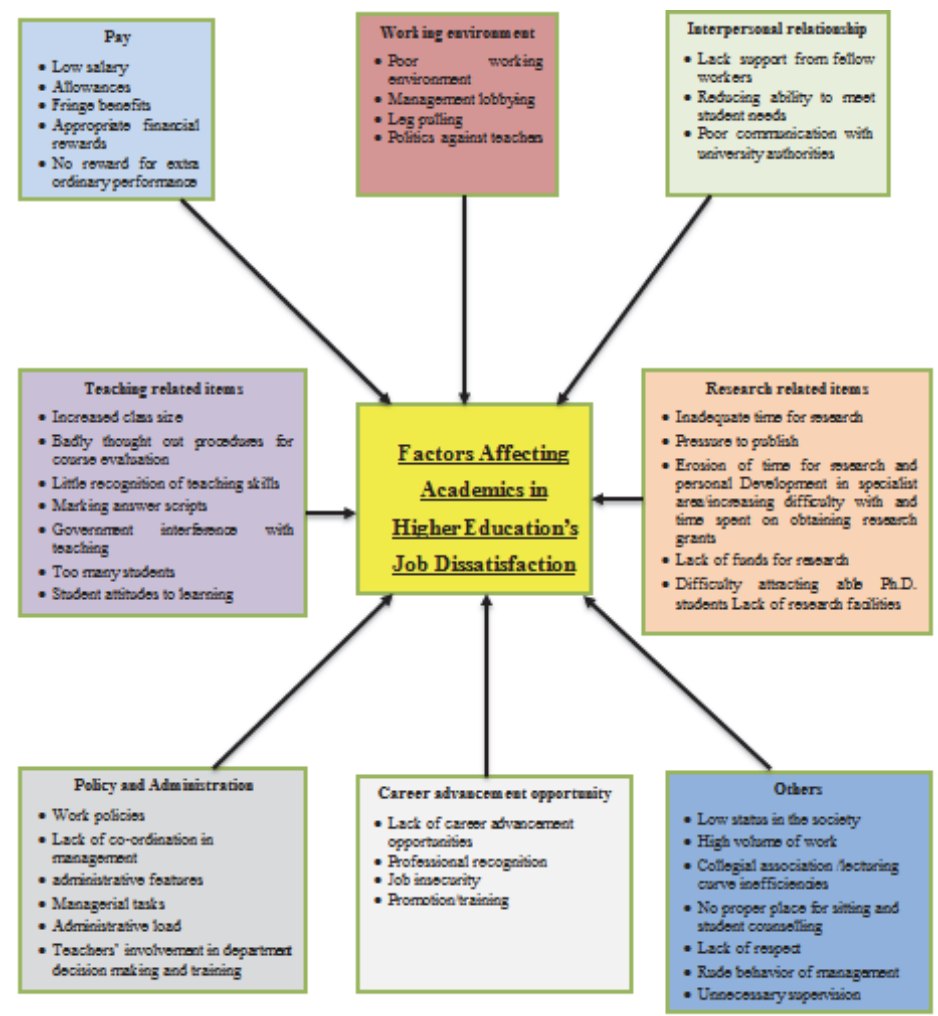

Figure 1. A Proposed Conceptual Framework Regarding Factors Affecting Academics' Job Dissatisfaction in Higher Education

\section{Disscussion, Conclusion and Recommendations}

The main objective of the study was to examine the factors affecting academics in higher education's job dissatisfaction. This study has revealed all the major factors that affect university academics. According to Herzberg's theory, the following characteristics - working conditions, supervision, interpersonal relationships, company policy and administration - are referred to as hygiene factors (Robbins, 2001: 75-76). Regardless of what theory is applied, issues such as pay, working environment, interpersonal relationships, teaching related issues, research related issues, policy and administration, and career advancement opportunities appear to be important factors for university academics in terms of their job dissatisfaction.

This study recommends that university academics should endeavour to know what factors affect their job dissatisfaction. Moreover, this study will help university academics to know which factors are likely to affect their job dissatisfaction.

\section{References}

Adelabu, M. A. (2005). Teacher motivation and incentives in Nigeria.

Adenike, A. (2011). Organizational climate as a predictor of employee job satisfaction: evidence from Covenant University. Business Intelligence Journal, 4(1), 157-166.

Afrol News n.d. Most South African educators dissatisfied with job.

Akpofure, R. R. Ikhifa, O. G. Imide, O. I. and Okokoyo, I. E. (2006). Job satisfaction among educators in colleges of education in southern Nigeria. Journal of Applied Sciences, 6(5), 1094-1098.

Alam, M. T. and Farid, S. (2011). Factors affecting teachers motivation. International Journal of Business and Social Science, 2(1).

Arnold, H. J. and Feldman, D. C. (1996). Organizational Behaviour. McGraw Hill.

Brown, A. K. and Mitchell, T. (1993). Organizational obstacles: links with financial performance, customer satisfaction, and job satisfaction in a service environment. Human Relations, 46(6), 725-733.

Chen, S. H. Yang, C. C, Shiau, J. Y. and Wang, H. H. (2006). The development of an employee satisfaction model for higher education. The TQM Magazine, 18(5), 484-500.

Chimanikire, P. Mutandwa, E. Gadzirayi, C. T. Muzondo, N. and Mutandwa, B. (2007). Factors affecting job satisfaction among academic professionals in tertiary institutions in Zimbabwe. African Journal of Business Management, 1(6), 166-175. 
Chung, K. H. (1977). Motivational Theories and Practices. USA, Columbus.

Croucher, K. Quilgars, D. Wallace, A. Baldwin, S. and Mather, L. (2003). Paying the mortage. A systematic literature review of safety nets for home owners, York: Department of Social Policy and Social Work.

David, B. Wesson, T. (2001). A comparative analysis among public versus private sector professionals. The Innovation Journal, 19(15), 28-45.

Day, C. (2002). The challenge to be best: reckless curiosity and mischievous motivation. Teacher and Teaching: Theory and Practice, 8(3), $421-434$.

Denizer, D. (2008). Accidents at work and work related health problems by sex, status, age and severity. Journal of Health Management, 26(2), $721-760$.

Dickter, D. Roznowski, M. and Harrison, D. (1996). Temporal tempering: An event history analysis of the process of voluntary turnovers. Journal of Applied Psychology, 81, 705-716.

Evdokia, K. (2009). How satisfied are Greek EFL teachers with their work? Investigating the motivation and job satisfaction levels of Greek FEL teachers, 59, 59-78.

Gellatly, I. R. (2005). Individual and group determinants of employee absenteeism: A test of a causal model. Journal of Organisational Behaviour, 16(1), 469-446.

Hargreaves, A. (1994). Changing Teachers, Changing Times. Cassell, London.

Hargreaves, A. (1998). The emotional practice of teaching, teaching and teacher education, 14(8), 835-854.

Herzberg, F. (1987). One more time: How do you motivate employees? Harvard Business Review, 65(5), 109-120.

Hoogendoorn, W. E. (2011). High physical work load and low job satisfaction increase the risk of sickness absence due to low back pain: Results of a prospective cohort study. Occupational and Environmental Medicine, 59(5), 323-328.

Houtte, V. M. (2006). Tracking and teacher satisfaction: Role of study culture and trust. Journal of Educational Research, 99(4): 247-256.

Hoy, W. K. and Miskel, C. G. (1991). Educational Administration Theory, Research and Practice. New York: Ramdon House.

Khalid, S. Irshad, M. Z. and Mahmood, B. (2012). Job satisfaction among academic staff: A comparative analysis between public and private sector universities of Punjab, Pakistan. International Journal of Business and Management, 7(1).

Lee, R. (1972). Relationship of selected demographic characteristics and the job satisfaction of industrial art teachers (Doctoral dissertation, Missouri University). Dissertation Abstracts International, VT020117.

Lee, T. (1988). How job dissatisfaction leads to turnover. Journal of Business and Psychology, 2, 263-271.

Lee, T. Mitchell, T. Holtom, B. McDaniel, L. and Hill, J. (1999). The unfolding model of voluntary turnover: A replication and extension. Academy of Management Journal, 42, 450-462.

Madison, D. (2000). Can your job make you sick? [Online] Available: http://www.keepmedia\%20\%20Psychology20Today.

Melamed, S. Ben-Avi, I. Luz, J. and Green, M. (1995). Objective and subjective work monotony: Effects on job satisfaction, psychological distress, and absenteeism in blue-collar workers. Journal of Applied Psychology, 80(1), 29-42.

Moses, I. (1986). Promotion of academic staff. Higher Education, 15, 33-37.

Olaitan, S. O. (1987). Correlates of job satisfaction of academic staff of Nigerian universities: A

case study of university of Nigeria, Nsukka. International Journal of Educational Research, 74-75.

Oshagbemi, T. (1997). The influence of rank on the job satisfaction in higher education. Education and Training, 39, 354-359.

Payne, R. L. and Morrison, D. (2002). The differential effects of negative affectivity on measures of well-being versus job satisfaction and organisational commitment. Journal of Organisational Behaviour, 24(3), 415-441.

Pearson, D. A. and Seiler, R. E. (1983). Environmental satisfiers in academe. Higher Education, 12, 35-47.

Perie, M. and Baker, D. (1997). Job Satisfaction among America's Teachers: Effects of Workplace Conditions, Background Characteristics and Teacher Compensation. Washington, D.C.: National Center for Education Statistics.

Ping, Du. Manhong, Lai. and Leslie, NKLo. (2010). Analysis of job satisfaction of university professors from nine Chinese Universities, Front. Educ China, 5(3), 430-449.

Redfern, S. H. (2005). Work satisfaction, stress, quality of care and morale of older people in a nursing home. Health and Social Care in the Community, 10(6), 512-517.

Robbins, S. P. (2001).Organisational Behaviour. New Jersey, Prentice Hall.

Sagie, A. (2002). Employee absenteeism, organisational commitment and job satisfaction: Another look. Journal of Vocational Behaviour, 52(2), $156-171$.

Santhapparaj, A. S. Srini, V. J. and Ling, K. L. (2005). Job satisfaction among women managers in Malaysia automobile manufacturing sector. Journal of Applied Sciences, 5(1), 1553-1578.

Schulze, S. (2006). Factors influencing the job satisfaction of academics in higher education. SAJHE, 20(2), 318-335.

Sekoran, U. and Jauch, L. R. (1978). Employee orientation and job satisfaction among professional employees in hospitals. Journal of Management, 4(4), 43-56.

Smith, W. T. (2007). Job Satisfaction in the United States, Embargoed for Release NORC/University of Chicago, [Online] Available: http://wwwnews.uchicago.edu/releases/07/pdf/070417.jobs.pdf.

Spears, M. Gould, K. and Lee, B. (2000). Who Would Be a Teacher? A Review of Factors Teacher Retention Unit: Teacher Retention Facts and Statistics. CPS Human Resources.

Ssesanga, K. and Garrett, R. M. (2005). Job satisfaction of university academics: Perspectives from Uganda. Higher Education 50, 33-56.

Sudalaiyandi, S. N. and Celia, B. R. J. (2011). A Study on the impact of work load on the job satisfaction of teaching staff in self financing engineering colleges recognised by Anna University of Technology, Tirunelveli. The International Journal of Research of Social Science and Management, 1(5).

Tye, B. B. and O'Brien, L. (2002). Why are experienced teachers leaving the profession? Phi Delta Kappan, 84(1), 24-32.

Wallace, A., Bevan, M., Croucher, K., Jackson, K., O'Malley, L., and Orton, V. (2005). The impact of empty, second and holiday homes on the sustainability or rural communities-a systematic literature review. The centre for housing policy, The University of Yor, 1-142.

Wong, E. S. K. and Heng, N. T. (2009). Case study of factors influencing job satisfaction in two Malaysian Universities. International Business Research, 2(2).

Zainudin, A. Junaidah, H. A. and Nazmi, M. Z. (2010). Modelling job satisfaction and work commitment among lecturers: A case of UITM Kelantan. Journal of Statistical Modeling and Analytics, 1(2), 45-59.

Zembylas, M. (2004). Job satisfaction among school teachers in Cyprus. Journal of Educational Administration, 42(3), 357-374. 